Volume 2

Number 32015 Student Articles Edition

Article 5

2015

\title{
Rethinking "Host" and "Guest" Relations in the Advent of Airbnb and the Sharing Economy
}

Michelle Maese

Texas A\&M University School of Law

Follow this and additional works at: https://scholarship.law.tamu.edu/journal-of-property-law

Part of the Law Commons

\section{Recommended Citation}

Michelle Maese, Rethinking "Host" and "Guest" Relations in the Advent of Airbnb and the Sharing Economy, 2 Tex. A\&M J. Real Prop. L. 481 (2014).

Available at: https://doi.org/10.37419/JPL.V2.I3.5

This Student Article is brought to you for free and open access by Texas A\&M Law Scholarship. It has been accepted for inclusion in Texas A\&M Journal of Property Law by an authorized editor of Texas A\&M Law Scholarship. For more information, please contact aretteen@law.tamu.edu. 


\title{
RETHINKING "HOST" AND "GUEST" RELATIONS IN THE ADVENT OF AIRBNB AND THE SHARING ECONOMY
}

\author{
By Michelle Maese ${ }^{\dagger}$
}

I. Introduction ............................... 482

II. Airbnb And the Sharing Economy .............. 485

A. The Sharing Economy .................... 485

1. Precursor and Evolution of the Sharing

Economy ........................... 486

2. Sharing Economy Model .............. 487

3. Future Implications ................. 488

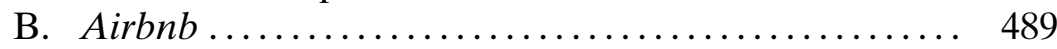

1. Humble Beginnings ................. 489

2. From Humble Beginnings to Billionaires ...... 490

3. Role in the Sharing Economy ............ 491

III. Intersection Between Airbnb, the Sharing

Economy, And Traditional Legal Frameworks .. 491

A. Landlord and Tenant Law ................... 492

1. Historical Context ................... 492

2. Modern Developments .................... 494

3. The Landlord and Tenant Relationship ....... 495

B. The Law of Innkeepers ..................... 498

1. Historical Context ....................... 498

2. Modern Developments ............... 500

3. The Innkeeper and Guest Relationship ....... 501

IV. Analysis of the Airbnb "Host" and "Guest"

RELATIONSHIP ................................ 502

A. Landlord and Tenant Law and the Law of

Innkeepers Distinguished.................. 502

B. Classifying Airbnb "Hosts" and "Guests" ......... 503

C. Approach to Regulation ....................... 505

D. Policy Arguments for Regulating Airbnb .......... 506

1. Protecting Airbnb Hosts and Guests.......... 506

2. Judicial and Administrative Efficiency ........ 508

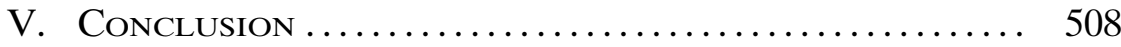

$\dagger$ J.D. Candidate May 2016, Texas A\&M University School of Law; B.A., 2009 University of Dallas. The Author thanks the following people: Frederic White, Former Dean and Retired Professor of Law, for inspiring the topic of this Article; Aric Short, Vice Dean, for his guidance and advice throughout the writing process; my parents, Carlos and Sharon, for their endless support and encouragement; and most of all, my son, Samuel, for being a constant source of joy and inspiration.

DOI: https://doi.org/10.37419/JPL.V2.I3.5 


\section{INTRODUCTION}

Cory Tschogl is a rehabilitation therapist who lives in the San Francisco Bay Area. ${ }^{1}$ Because Tschogl was "priced out" of buying a home in the Valley, she decided to invest in a vacation rental condominium ("condo") in Palm Springs, California. ${ }^{2}$ In order to make ends meet with the higher rents in San Francisco, Tschogl had been renting her condo to travelers through the hugely popular company, Airbnb, ${ }^{3}$ which provides an online platform for travelers seeking short-term accommodations to connect with individuals who have space to rent in their homes. ${ }^{4}$ According to Tschogl, this arrangement had worked well for a year until she was contacted through Airbnb by a potential guest who told Tschogl he needed "accommodations for an extended business trip" and asked to rent her condo for a little more than a month. ${ }^{5}$ Tschogl's initial interactions with this guest "seemed OK," so she agreed to rent her condo to him from May 25 to July 8, a total of forty-four days. ${ }^{6}$ In retrospect, however, Tschogl admits the fact that the guest did not have any reviews on Airbnb should have been a warning sign, and soon enough, what should have been a simple shortterm rental arrangement turned into a nightmare for Tschogl. ${ }^{7}$

It started out innocently enough. On the first day after Tschogl's guest checked in he called to complain about two odd things. ${ }^{8}$ First, the guest complained that he did not like the tap water because it "was cloudy," and second, he did not like the gated entry to the complex. ${ }^{9}$ Tschogl's guest asked for a full refund to which Tschogl readily agreed because Tschogl had a "bad gut feeling" about him. ${ }^{10}$ Tschogl contacted Airbnb immediately, and after multiple emails and phone calls, the company responded two days later stating it had asked the guest to leave and that Tschogl was entitled to keep an appropriate portion of the guest's fee in consideration of the two days he stayed in the condo. ${ }^{11}$ So what is the problem? Tschogl's guest decided to stay in the condo for the duration of the rental term despite the fact that the guest asked for a refund and was subsequently asked to vacate the

1. Julie Bort, Airbnb Host: A Guest is Squatting In My Condo and I Can't Get Him to Leave, SF GATE (July 21, 2014, 10:48 AM), http://www.sfgate.com/technology/businessinsider/article/Airbnb-Host-A-Guest-Is-Squatting-In-My-Condo-And5638090.php.

2. $I d$.

3. $I d$. 2014).

4. About Us, AirBnB, https://www.airbnb.com/about/about-us (last visited Oct. 5,

5. Bort, supra note 1.

6. Id.

7. $I d$.

8. $I d$.

9. $I d$.

10. $I d$.

11. $I d$. 
condo by both Tschogl and Airbnb. ${ }^{12}$ At a loss for what to do, and after trading several antagonistic texts with the guest, Tschogl decided to let the guest remain in the condo for the remainder of his reservation. ${ }^{13}$ Then on June 25, Airbnb again contacted the guest after it was unable to collect payment for the last part of the reservation and warned the guest either to pay or to leave-he did neither. ${ }^{14}$ Finally, on the last day of the reservation Tschogl sent the guest a text warning him that the utilities would be shut off if he did not vacate the premises. ${ }^{15}$ Tschogl's guest responded in kind, threatening to press charges for "blackmail and damages caused by [Tschogl's] negligence and malicious misconduct ... as well as medical bills for [his] brother's hospital visit" after he "got sick" from drinking the murky tap water. ${ }^{16}$ Tschogl's guest further asserted he was legally occupying the condo and that he had rights. ${ }^{17}$ Moreover, the guests claimed that loss of electricity would threaten the work he does which brings in between $\$ 1,000$ to $\$ 7,000$ a day. ${ }^{18}$ As it turns out, Tschogl's guest was not totally wrong. ${ }^{19}$ After hiring a lawyer Tschogl discovered that, in California, a person who rents property for at least thirty days is considered a tenant on a month-to-month lease. ${ }^{20}$ Thus, Tschogl's guest was afforded some protection under California law, and therefore, could not be forced to vacate the property without Tschogl first taking appropriate legal measures. In this case, getting Tschogl's guest to leave required a full-blown eviction proceeding, which typically take between three to six months and can cost anywhere from $\$ 3,000$ to $\$ 5,000$ in legal fees. ${ }^{21}$ After Tschogl contacted two news outlets to share her story, Airbnb responded saying it had apologized for not meeting its own standards and that Tschogl would be fully refunded the cost of the reservation. ${ }^{22}$ Airbnb also promised to provide additional support moving forward, although it was ultimately up to Tschogl to follow through with legal proceedings and evict the Airbnb guest-turned-squatter. ${ }^{23}$

It is unlikely Tschogl ever thought she would find herself in a situation such as she did when looking for a way to supplement her income. While Tschogl does not blame Airbnb entirely for what
12. $I d$.
13. Id.
14. $I d$.
15. Id. hosts-5631952.php.
17. Bort, supra note 1.
18. Said, supra note 16.
19. Bort, supra note 1.
20. $I d$.
21. $I d$.
22. Id.
23. $I d$.

16. Carolyn Said, Squatters Don't Sit Well With Airbnb Hosts, SF GATE (July 25, 2014), http://www.sfgate.com/realestate/article/Squatters-don-t-sit-well-with-Airbnb- 
happened, she believes Airbnb could do more to educate individuals who rent space in their homes through Airbnb's website, respond more quickly when problems arise, and perhaps even insure them. ${ }^{24}$ As it stands now, Airbnb simply warns users that it is their responsibility to know the laws of their city in order to avoid situations such as the Tschogl encountered. ${ }^{25}$

Airbnb is one example of the "Sharing Economy" whereby owners and consumers connect to share "space, skill, and stuff" for monetary and non-monetary benefits. ${ }^{26}$ Although this concept is not a new one ${ }^{27}$ it has garnered much attention recently due to the proliferation of internet start-ups, which, like Airbnb, connect owners and consumers both easily and efficiently. ${ }^{28}$ The increasing relevance of the Sharing Economy, and likely continued success of Airbnb, provides an opportunity to consider how Airbnb fits into traditional legal frameworks and evaluate whether states and municipalities should enact laws regulating Airbnb.

Part II of this Article introduces the concept of the Sharing Economy, outlines different systems within it, and suggests reasons for its success as well as future implications. Part II further considers the inception of Airbnb and potential for its continued success before briefly discussing how Airbnb fits into the Sharing Economy, overall. Part III focuses on the legal relationship that is created when, using the platform Airbnb provides, individuals rent space in their homes to travelers seeking short-term accommodations. Specifically, this relationship will be considered in the context of two distinct and longstanding areas of law: landlord and tenant law and the law of innkeepers. Part III traces the historical roots and evolution of both these areas of law with particular attention paid to the different rights and obligations of the parties within each body of law. This Section provides the general framework for Part IV in which the Author argues that the relationship between Airbnb "hosts" and "guests" is not so easily defined under current law. That is, in individual cases a landlord-tenant relationship may be created, whereas in other circumstances the relationship may bear a closer resemblance to that of an innkeeper and his guest. Part IV then considers policy arguments in support of regulating Airbnb before concluding the Airbnb host and

24. Id.

25. Id.; What Legal and Regulatory Issues Should I Consider Before Hosting on Airbnb?, AirbnB, https://www.airbnb.com/help/article/376 (last visited Aug. 17, 2015).

26. See Molly Cohen \& Corey Zehngebot, What's Old Becomes New: Regulating the Sharing Economy, 58 B.B.J 6 (2014).

27. See id.; Tina Rosenberg, It's Not Just Nice to Share, It's the Future, N.Y. TIMEs (June 5, 2013, 9:00 AM), http://opinionator.blogs.nytimes.com/2013/06/05/its-not-justnice-to-share-its-the-future/.

28. See Tomio Geron, Airbnb and the Unstoppable Rise of the Share Economy, Forbes (Jan. 23, 2013, 6:00 AM), http://www.forbes.com/sites/tomiogeron/2013/01/23/ airbnb-and-the-unstoppable-rise-of-the-share-economy/. 
guest relationship is best understood in terms of the law of innkeepers and should be regulated accordingly.

\section{Airbnb and the Sharing Economy}

Airbnb is a self-described "community marketplace for people to list, discover, and book unique accommodations around the worldonline or from a mobile phone." 29 Based in San Francisco and founded in 2008, the company operates through its website to match vacationers seeking affordable short-term accommodations with people who have room to rent in their homes-all for a reasonable price, of course. ${ }^{30}$ Airbnb exemplifies what many commentators have termed the Sharing Economy. ${ }^{31}$ That is, the Sharing Economy is meant to refer to a new kind of capitalism made possible by advances in technology whereby individuals can connect with consumers through online platforms to "share" their assets for profit. ${ }^{32}$ At first glance, this arrangement seems like a win-win situation for all the parties involved. After all, with regard to Airbnb, individuals are more likely to travel if they can find inexpensive, alternative solutions to commercial lodging, which, in turn, injects money into local economies. ${ }^{33}$ Renters are likewise at an advantage because Airbnb allows them to easily convert unused space in their homes into extra income. ${ }^{34}$ Despite these advantages, however, Airbnb's success has not come without controversy. ${ }^{35}$ At the heart of this problem is the fact that Airbnb and similar companies participating in the Sharing Economy simply do not fit into traditional legal frameworks, which leaves many local governments struggling with the question of whether to enact laws regulating Airbnb and, if so, to what extent. ${ }^{36}$

\section{A. The Sharing Economy ${ }^{37}$}

To better understand the Sharing Economy, it is important to first understand some of the economic conditions that existed in America

29. About Us, supra note 4. Indeed, Airbnb's app has more than one million downloads and accounts for approximately $25 \%$ of the company's users. Jordan Crook, Airbnb's Big 2012, TechCrunch (Feb. 7, 2013), http://techcrunch.com/2013/ 02/07/airbnbs-big-2012-4x-guest-growth-and-2x-the-number-of-listings-in-over-150countries-worldwide/.

30. About Us, supra note 4.

31. See Geron, supra note 28.

32. See Rosenburg, supra note 27.

33. See The Economic Impacts of Home Sharing, AIRBNB, https://www.airbnb .com/economic-impact/ (last visited Dec. 29, 2014) (noting "travelers stay longer and spend more" throughout the city).

34. See About Us, supra note 4.

35. See Cohen \& Zehngebot, supra note 26 , at 7,8 .

36. Charles Gottlieb, Residential Short-Term Rentals: Should Local Governments Regulate the "Industry"?, 65 PlanNING \& ENVTL. L No. 2, p.4.

37. The term sharing economy has also been referred to variously as "collaborative consumption," the "asset-light lifestyle," the "collaborative economy," 
prior to the sharing revolution, which, in turn, contributed to this phenomenon. Next, the particular functions and qualities attributable to the success of the Sharing Economy are considered. Finally, the future implications of the Sharing Economy are briefly discussed.

\section{Precursor and Evolution of the Sharing Economy}

Beginning in the 19th century a class of young and well-to-do individuals emerged eager to showcase their wealth and social power. ${ }^{38}$ This class (later termed the "nouveau riche") lavished money on expensive items such as clothes, jewelry, and cars in order to show that, not only were they prosperous, but that they were different from "the masses." 39 Thus, the consumer emphasis at this time was not on the necessity or utility of goods, but rather on the buying power of the individual, which, in turn, was directly linked with wealth and social status. ${ }^{40}$ This trend became prominent in America during the 1920s, while the mid-1950s witnessed the dawn of "hyper-consumerism," a term that was used to describe the American consumer's endless quest to acquire "more stuff in ever greater amounts." 41 What accounted for the sudden and rapid growth of American consumerism? Commentators have identified at least four major sources that played a critical role in feeding this phenomenon: the power of persuasion; ${ }^{42}$ the buy now, pay later culture; ${ }^{43}$ the law of life cycles; ${ }^{44}$ and the "just one more" factor. ${ }^{45}$ Over the past fifty years, however, it appears that

"peer economy," or the "access economy." The Sharing Economy: All Eyes on the Sharing Economy, THE ECONOMIsT (Mar. 9, 2013), http://www.economist.com/news/ technology-quarterly/21572914-collaborative-consumption-technology-makes-iteasier-people-rent-items.

38. Rachel Botsman \& Roo Rogers, What's Mine is Yours: The Rise of Collaborative Consumption 20 (HarperCollins Publishers 2010).

39. Id. It was at this time that Norwegian economist and sociologist Thorstein Veblen coined the term "conspicuous consumption" to describe the lifestyle and spending habits of the nouveau riche. Id.

40. See id.

41. Id.

42. Botsman \& Roo, supra note 38, at 21-23. The "power of persuasion" simply means appealing to an individual's desire to be attractive, fit, rich, powerful, etc. in order to sell a particular good, or what we commonly refer to as advertising. Id.

43. $I d$. at 26. This refers to the influence of credit cards on our spending decisions. $I d$. Studies have shown that credit cards alter our perception of the value of a product and that using a credit card detaches the act of purchase from payment. Id. at 28-29. These and other reasons lead to a simple credit equation: "The more credit we have, the more stuff we can afford to buy, the more resources consumed, and the more waste created." Id. at 30 .

44. All electronic consumer products, from cell phones to home appliances and even cars, have a life cycle. $I d$. at 33,36 . The fact that these products will eventually "expire" contributes to hyper-consumerism because Americans continue to purchase these products over the course of their lifetime. See id. at 37. This situation is made worse by the fact Americans often discard products still in the prime of their life in order to acquire the next "new thing," and moreover, many companies shorten the lifetime of their products to increase sales. $I d$.

45. Botsman \& Roo, supra note 38, at 21. 
American hyper-consumerism has slowed down and is slowly being replaced with a new consumer model-Collaborative Consumption, also termed the Sharing Economy. ${ }^{46}$ This has occurred for two reasons: the first, a shift in values; ${ }^{47}$ and the second, a reemerging focus on the collective good rather than the good of the individual. ${ }^{48}$ The value shift recognizes that unrestrained individual consumerism is detrimental to our communities, the environment, and our personal relationships. ${ }^{49}$ This realization has led consumers to find ways to maximize the utility of goods both that they buy, and that they do not buy, while simultaneously re-strengthening community ties. In other words, the former doctrine of consumer excess is being replaced with a social and economic system that balances the needs of individuals with the needs of communities and the planet. ${ }^{50}$

\section{Sharing Economy Model}

Participants in the Sharing Economy play two roles. ${ }^{51}$ First, a person may act as a "peer provider" by providing assets to rent, share, or borrow. ${ }^{52}$ In contrast, a "peer user" consumes the available products and services. ${ }^{53}$ Examples of the Sharing Economy abound and vary in scale, purpose, and stage of development. ${ }^{54}$ Generally, these can be organized into three categories: product service systems, redistribution markets, and collaborative lifestyles. ${ }^{55}$ Product service systems enable people to enjoy the benefit of a product without having to purchase the product outright, ${ }^{56}$ whereas redistribution markets enable used or pre-owned goods to be redistributed from areas where they are not needed to areas where they are based on free exchange, sale, barter, or a combination. ${ }^{57}$ Underlying each of these systems within the Sharing Economy are four principles that have been key to its success: critical mass, idling capacity, belief in the commons, and trust between strangers. ${ }^{58}$ The fourth and perhaps most important

46. Id. at 44,63 .

47. Id. at 44. This value shift is premised on a "growing consumer consciousness that finite growth and consumption based on infinite resources are not a viable combination." Id.

48. Id.

49. Id.

50. Botsman \& Roo, supra note 38 , at 63.

51. $I d$. at 70 .

52. Id.

53. Id.

54. Id. at 71. These include tool exchanges, land share, clothing swaps, ride sharing, CouchSurfing, and time banks, to name a few. Id.

55. $I d$.

56. Id.

57. Id. at 72 .

58. Id. at 75. The first principal, critical mass, describes the existence of enough momentum within a particular system that it becomes self-sustaining. Id. Critical mass is crucial to the success of Sharing Economy systems for two reasons. First, it provides consumers with a wide array of products and services to choose from, and when con- 
principle in collaborative lifestyle systems, such as Airbnb, is trust between strangers. ${ }^{59}$ In contrast to the hyper-consumerism model, where an intermediary facilitates the transaction between production and consumption, the Sharing Economy eliminates the need for an intermediary, and instead, replaces it with platforms that enable peer-topeer transactions. Although companies that provide these platforms are, in a sense, acting as intermediaries, they are not there to police these transactions, but rather to act as "curators and ambassadors" in facilitating these peer-to-peer exchanges and contributions to the marketplace. ${ }^{60}$

\section{Future Implications}

Although the Sharing Economy is being touted as a revolutionary new idea, in fact, in some fields it has been around for millennia. ${ }^{61}$ However, an integral part of the Sharing Economy-the means by which consumers connect with one another to share resources-is being revolutionized due to advances in technology and, in particular, the recent proliferation of internet start-ups, which create digital platforms that connect consumers both easily and efficiently. ${ }^{62}$ This is significant for several reasons. For one, the Sharing Economy shows consumers that happiness is not defined solely in terms of material goods; instead, happiness takes on a broader meaning as less emphasis is placed on individual ownership of goods and more on community exchanges. ${ }^{63}$ Second, an individual consumer's reputation will have heightened importance, as this will often determine access to the Sharing Economy as well as the extent of a consumer's power and influence therein. ${ }^{64}$ Finally, the Sharing Economy will likely continue to promote entrepreneurism and the establishment of new businesses. ${ }^{65}$

sumers are satisfied with the available choices, they are more likely to be pleased with the overall experience of acquiring these products or services. Id. at 75-76. Second, critical mass engenders a core group of frequent and loyal users, which help to not only sustain the system, but also grow it by attracting consumers that might have not otherwise chosen to participate. Id. at 82. In other words, otherwise reluctant consumers can feel comfortable participating in the Sharing Economy because they can see that "everyone else is doing it." Id. The second principle, idling capacity, refers to the unused potential of items when they are not in use and considers how this potential can be redistribution to maximize an item's productivity and usage. $I d$. at $83-84$. The third principle, the belief in "the commons" has been widely understood to mean that individuals, acting in their own short term self interests, will misuse and overuse shared resources and that because of this "tragedy is inevitable." Id. at 88-89. History, however, has demonstrated this is not always the case, and in the context of the Sharing Economy, the more participants there are the better the system works, meanwhile value is created for the individual. $I d$. at $90-91$.

59. Id. at 91 .

60. Id. at 92 .

61. Rosenburg, supra note 27.

62. Geron, supra note 28.

63. Botsman \& Roo, supra note 38, at 217.

64. See id. at 217-20.

65. See id. at 220-23. 
In summary, the Sharing Economy meets the same consumer needs as under the hyper-consumerism model while at the same time addressing waste and environmental issues, reducing the number of new products and raw materials consumed, and changing the consumer mind-set from one of individual self-interest to that of the collective good. ${ }^{66}$ Whatever impact the Sharing Economy will have on the future, one thing is certain-with at least 100 companies sprouting up over the past four years eager to participate in this new market, ${ }^{67}$ and with estimated revenues in excess of $\$ 3.5$ billion-the new, revolutionized Sharing Economy is a phenomenon that is here to stay.

\section{B. Airbnb}

The following Section details Airbnb's inception and potential for continued success before briefly discussing the role Airbnb plays in the Sharing Economy overall.

\section{Humble Beginnings}

It all started with two friends, three air mattresses, and the need for some fast cash in order to pay the rent. In October of 2007, future Airbnb co-founder Brian Chesky was a recent graduate of the Rhode Island School of Design. ${ }^{68}$ After working a while for a Los Angeles design firm, Chesky became "fed up" and left his job for San Francisco to stay at the home of his good friend and future Airbnb cofounder Joe Gebbia, who agreed to split the cost of rent with Chesky. ${ }^{69}$ At the time, Chesky's share of the rent came to $\$ 1,150$, but the now unemployed Chesky only had $\$ 1,000$ in the bank. ${ }^{70}$ Fortunately, the two friends had an idea to make some quick money. ${ }^{71}$ It just so happened that the week Chesky arrived in town, San Francisco was hosting the Industrial Designers Society of America and there were no more available hotel rooms in the area for conference attendees. ${ }^{72}$ Chesky and Gebbia had the idea of turning their house in to a bed and breakfast for the attendees; however, instead of beds the two friends only had air mattresses to offer their guests. ${ }^{73}$ So Chesky and Gebbia inflated the mattresses, advertised themselves online as "Airbed and Breakfast," and successfully hosted three people at a rate

66. Id. at 213.

67. Geron, supra note 28.

68. Thomas Friedman, Welcome to the Sharing Economy, N.Y. Times, (July 20, 2014), http://www.nytimes.com/2013/07/21/opinion/sunday/friedman-welcome-to-thesharing-economy.html? pagewanted=all.
69. Id.
70. $I d$.
71. $I d$.
72. $I d$.
73. $I d$. 
of $\$ 80$ a night. ${ }^{74}$ Because of their resourcefulness (and with the help of a few spare air mattresses), Chesky and Gebbia were able to pay the rent that month, and ultimately, this experience lead to a much bigger idea-namely, to create a global network connecting individuals with space to rent in their homes with travelers seeking short-term rental accommodations. ${ }^{75}$ With this goal in mind, Chesky, Gebbia, and Nathan Blecharczyl (who was brought on board to oversee technical strategy) founded Airbnb in August 2008 in San Francisco, California. $^{76}$

\section{From Humble Beginnings to Billionaires}

Airbnb, which was named in homage to its roots, ${ }^{77}$ has a broker's model, taking a $3 \%$ cut from the renter and a $6 \%$ to $12 \%$ cut from the traveler, depending on the property price, in exchange for providing the market and services such as customer support, payment handling, and eventually insurance for its hosts. ${ }^{78}$ After an initial slow start, things began to change when, in order to attract a larger customer base, Airbnb began focusing its efforts on New York eventually ending the year with 100,000 guest nights booked. ${ }^{79}$ Encouraged by its success in New York, Airbnb added additional features to help entice customers such as escrow payments and professional services to photograph listings. ${ }^{80}$ The company even expanded the different kinds of spaces for rent to include "whole houses, driveways and even castles and tree houses." 81 These and other changes led to rapid growth; by 2010, Airbnb had gone international and total guest nights booked rose to $750,000 .{ }^{82}$ By 2011, total guest nights booked exceeded 2 million. ${ }^{83}$

Since its launch in 2008, Airbnb claims to have connected more than 40 million travelers with short-term renters (or in Airbnb parlance, "hosts" and "guests") ${ }^{84}$ and boasts a presence in more than 34,000 cities and 190 countries, with listings exceeding 1 million worldwide. ${ }^{85}$ Airbnb has continued to expand its diverse accommodation

74. Id. True to their name, Chesky and Gebbia also served their guests breakfast and acted as local tour guides. $I d$.

75. Id.

76. About Us, supra note 4; Our Co-Founders, Airbnb, https://www.airbnb.com/ about/founders (last visited Oct. 12, 2014); Geron, supra note 28.

77. Friedman, supra note 68.

78. Geron, supra note 28.

79. $I d$.

80. $I d$.

81. Id.

82. $I d$.

83. Id.

84. See Terms of Service, Airbnb, https://www.airbnb.com/terms (last visited Oct. 12, 2014).

85. About Us, supra note 4. 
offerings to include more than 600 castles, ${ }^{86}$ as well as more exotic listings such as a two bedroom suite carved out of an old Boeing 727, or an igloo complex in Krvavec, Slovenia. ${ }^{87}$ After its most recent round of fundraising in April 2014, Airbnb raised approximately $\$ 450$ billion at a $\$ 10$ billion valuation, confirming Airbnb co-founders Chesky, Gebbia, and Belcharczyk as the new Sharing Economy's first billionaires. ${ }^{88}$

\section{Role in the Sharing Economy}

Airbnb users fall into one of the two previously discussed roles, that of "peer provider" or "peer user." Airbnb hosts who advertise space for rent in their homes play the role of peer providers, whereas Airbnb guests who book these accommodations through Airbnb are peer users. Although Airbnb provides the platform for hosts and guests to connect, the individual hosts and guests ultimately negotiate and agree upon the rental terms. This arrangement falls within the collaborative lifestyle system where the peer-to-peer interaction is the focus of the exchange and not a physical product. ${ }^{89}$ It is because of this that a higher degree of trust is often required with collaborative lifestyles than with product service systems or redistribution markets. Indeed, as many commentators have noted, Airbnb's real innovation is not so much online rentals as it is "trust." $"$ In essence, Airbnb has created a framework of trust in which millions of people feel comfortable renting space in their homes to complete strangers, and it is largely because of this trust that Airbnb owes its success. ${ }^{91}$

\section{Intersection Between Airbnb, the Sharing Economy, and Traditional Legal Frameworks}

The Sharing Economy has changed the way consumers access goods and services by both redefining the production-to-consumer model in terms of peer-to-peer exchanges, and providing numerous platforms for doing so. ${ }^{92}$ Airbnb, in particular, has revolutionized the way consumers travel by facilitating short-term rental accommodations in the homes of individuals, rather than corporate chain hotels or other similar lodgings. ${ }^{93}$ The benefits of this arrangement are that consumers

86. $I d$.

87. Morgan Brennan, The Most Amazing and Absurd Places for Rent, Forbes (Sept. 16, 2011, 4:51 PM), http://www.forbes.com/sites/morganbrennan/2011/09/16/themost-amazing-and-absurd-places-for-rent/.

88. Alex Conrad, Airbnb Cofounders are Billionaires, Forbes (Apr. 18, 2014, 4:55 PM), http://www.forbes.com/sites/alexkonrad/2014/04/18/airbnb-closes-round-at-10billion/.

89. Botsman \& Roo, supra note 38 , at 73.

90. Id.

91. Id.

92. See All Eyes on the Sharing Economy, supra note 37.

93. About Us, supra note 4. 
typically spend less on rental accommodations; are able to stay longer and spend more money at their destinations of choice; and can enjoy the human interaction with their Airbnb hosts. ${ }^{94}$ Notwithstanding, Airbnb has not been without its fair share of criticism; ${ }^{95}$ the majority of this criticism, however, has focused on the effects ancillary to the short-term rental transaction with little attention being paid to the legal relationships created between Airbnb hosts and guest and consequent rights and obligations of the parties. ${ }^{96}$ Thus, in order to better understand the nature of this relationship, it is helpful to consider it within the context of two well-established areas of law: landlord and tenant law and the law of innkeepers.

\section{A. Landlord and Tenant Law}

An understanding of the common law origins of landlord and tenant law is essential to understanding its evolution and modern day application. The following Sections outline the progression of landlord and tenant law from status to property; discuss changes to this area of law brought on by modern day conditions and legislation; and finally consider the defining characteristics of the landlord and tenant relationship.

\section{Historical Context}

Landlord and tenant law has its roots in feudal England where, following the Norman Conquest in 1066, title to all lands were held by William the Conqueror, who divided it among his subjects by "leasing" the land in exchange for services, rather than granting outright ownership of the land. ${ }^{97}$ The feudal estate was further subdivided among subtenants who held the land in "free" or "unfree" tenure. ${ }^{98} \mathrm{~A}$ majority of the English population in the 11th century consisted of peasants who performed agricultural and other manual services, and thus, held their lands in "unfree tenure." 99 These individuals were referred to as "tenants in villeinage," and while they enjoyed legal status under the law, they had no contractual or property rights. ${ }^{100}$ Indeed, a

94. See The Economic Impacts of Home Sharing, supra note 33.

95. See Cohen \& Zehngebot, supra note 26 (noting concerns incident to the sharing economy in general); see generally Michael Hiltzik, Rental Sites Like Airbnb Aren't as Innocuous as They Pretend, L.A. Times (July 19, 2015, 5:00), http:// www.latimes.com/business/hiltzik/la-fi-hiltzik-20150719-column.html\#page=1; see generally Will Coldwell, Airbnb's Legal Troubles: What Are The Issues?, GuARDIAN (July 8, 2014), http://www.theguardian.com/travel/2014/jul/08/airbnb-legal-troubles-whatare-the-issues.

96. See Cohen \& Zehngebot, supra note 26 .

97. Jean C. Love, Landlord's Liability for Defective Premises, 1975 Wis. L. REv. 19, 23 (1975).

98. Id.

99. Id.; 1-4 Thompson on Real Property, Thomas Edition $§ 4.05(\mathrm{~b})$ (David A. Thomas ed., 3rd ed. LexisNexis 2014) [hereinafter Thompson].

100. Love, supra note 97, at 24. 
tenant in villeinage was a "tenant at the will of the lord" and could be ejected by his lord without recourse from the courts. ${ }^{101}$ Over time, the status of the villeinage tenant became more secure and was replaced by the tenancy for a term of years, thus marking the transition of the landlord and tenant relationship from one of status to contract. ${ }^{102}$ When the tenancy for years began to be used for agricultural purposes in the mid-1300s, the landlord and tenant relationship became viewed as purely contractual on the basis that a wrongfully dispossessed tenant only had an action against the landlord for breach of covenant. ${ }^{103}$ The era in which the lease was viewed primarily as a contract ended, however, with the development of the action of ejectment in the late 15 th century; by the 16th century, the notion of a lease as a conveyance of property was firmly entrenched in landlord and tenant law. ${ }^{104}$ As a result, the rights, duties, and obligations of landlords and tenants became defined according to property law principles. ${ }^{105}$

The society in which early landlord and tenant law developed was predominately rural and agrarian and, as such, the land was of principal importance. ${ }^{106}$ Often there were no structures on the land, and if there were they were of minimal importance. ${ }^{107}$ Under the typical agricultural lease, the landlord's principal obligation was to convey possession of the land to the tenant in return for which the tenant agreed to pay rent. ${ }^{108}$ Two important covenants were implied in every lease: first, the landlord's covenant to protect the tenant's "quiet enjoyment" of the premises; and second, the tenant's covenant to pay rent. ${ }^{109}$ These covenants were deemed independent of one another; thus, the breach by one party did not excuse the performance of the other. ${ }^{110}$ In other words, a tenant who failed to pay rent could remain in possession of the premises with the landlord's sole remedy being an action for damages as the rent accrued. ${ }^{111}$ Likewise, if a landlord breached the covenant of quiet enjoyment, the tenant's obligation to pay rent was not terminated; rather, the tenant's remedies were an

101. Id. In contrast, a villeinage tenant could protect his interest against ejection by a third party in the lord's courts. Id. Therefore, the villeinage tenant enjoyed a limited possessory interest by custom, although he was afforded mere status under the law. Id.

102. Id. Initially, the tenancy for a term developed as a means to obtain loans of money while avoiding the church's ban on usury. Robert H. Kelley, Any Reports on the Death of the Property Law Paradigm for Leases Have Been Greatly Exaggerated, 41 WAYNe L. Rev. 1563, 1573 (1995).

103. Love, supra note 97 , at 25.

104. Gary Goldman, Uniform Commercial Landlord and Tenant Act, 19 T.M. CooLEY L. REV. 175, 180 (2002).

105. See Kelley, supra note 102 , at 1565-66.

106. See id. at $1576-77$.

107. $I d$.

108. Love, supra note 97, at 32.

109. Id.

110. Goldman, supra note 104, at 181-82.

111. Love, supra note 97, at 32. 
action for possession and an action for damages for breach of the covenant. ${ }^{112}$ Another important doctrine that developed at this time was that of caveat lessee, which meant there was no implied warranty with regard to the "fitness and habitability of the premises for any particular purpose" and that the tenant agreed to accept the premises "as is." 113 From this rule followed the principle that the landlord was not liable in tort to the tenant (or to third parties) for injuries to person or property resulting from a defect in the premises. ${ }^{114}$ Thus, a landlord had no duty to deliver or maintain the premises in any particular condition and the tenant accepted the premises with any existing defects at the time of the lease. ${ }^{115}$ The tenant's only obligation with respect to the premises was to maintain and make such repairs as necessary to prevent waste. ${ }^{116}$

\section{Modern Developments}

During the Industrial Revolution, the population began to shift from rural to more urban settings, which increased the importance of structures on leased land for the purposes of shelter and conducting business. ${ }^{117}$ As a result, written lease transactions became more complex as parties frequently included express covenants to address concerns incident to leases in these urban areas. ${ }^{118}$ Noting the apparent change to the nature of the lease, commentators began to question whether the lease should be viewed as a contract or as a conveyance, with many opining it was both. ${ }^{119}$ Nonetheless, courts persisted in characterizing the lease as a conveyance in property, and real property law continued to govern the landlord and tenant relationship. ${ }^{120}$

The 1960s and 1970s witnessed a revolution in landlord and tenant law resulting in the rejection of many traditional property-law principles (including the notion of a lease as a conveyance of land) and substitution in their place of new principles more in line with modern conditions. ${ }^{121}$ As many scholars have noted, this paradigm shift was attributed to three main causes: (1) legislative activity; ${ }^{122}$ (2) the pas-

112. $I d$.

113. Goldman, supra note 104, at 181-82.

114. Mary Ann Glendon, The Transformation of American Landlord-Tenant Law, 23 B.C. L. Rev. 503, 517 (1982).

115. Love, supra note 97, at 26.

116. Glendon, supra note 114 , at 511.

117. Love, supra note 97, at 26.

118. Id.

119. Id. at 27.

120. $I d$.

121. 2-16 Powell on Real Property \$16.01 (Michael Allan Wolf ed., LexisNexis Matthew Bender 2014) [hereinafter PowELL].

122. Goldman, supra note 104, at 183 . After World War II, public interest and intervention in the housing area increased, and in 1949 Congress passed the Housing Act with the goal of achieving "a decent home and suitable living environment for every living American." Glendon, supra note 114, at 519. In the ensuing years, many 
sage of the Uniform Residential Landlord Tenant Act ("URLTA"); ${ }^{123}$ and (3) modernization through the judiciary by applying contract principles to leases. ${ }^{124}$ Following this revolution, the departure from traditional principles of landlord and tenant law is most evident in the following areas: the landlord's obligation with respect to the premises; remedies available upon breach; tort liability; summary process proceedings; and termination of the lease. ${ }^{125}$

Although modern developments have substantially changed landlord and tenant law with respect to the rights and duties of the parties to a lease, these changes have not altogether supplanted the traditional rules. Thus, it is necessary to take into account both the old and the new in considering the application and interpretation of landlord and tenant law.

\section{The Landlord and Tenant Relationship}

In order for landlord and tenant law to apply in a particular situation, a landlord and tenant relationship must first be found to exist. In general, this relationship arises by agreement between the parties pursuant to which control of the landlord's premises is given over to the tenant in exchange for consideration, usually rent. ${ }^{126}$ The four defining characteristics of the landlord and tenant relationship are: (1) a reversion in the landlord; (2) the creation of an estate in the tenant (either at will or for a term less than that held by the landlord); (3) a transfer of exclusive possession and control to the tenant; and (4) an agreement between the parties, either express or implied. ${ }^{127} \mathrm{~A}$ tenancy is created when an owner of an estate in land transfers the exclusive possession of the land to another; absent such an agreement no

states and localities passed housing codes detailing health and safety standards; additionally, state legislatures began establishing new obligations for landlords as well as new rights and remedies for tenants. $I d$.

123. Goldman, supra note 104, at 183, 185-91. The URLTA was established to clarify and modernize the law governing residential leases and corresponding rights and obligations of landlords and tenants. Id. at 185-86. The URLTA helped usher in a new era by shifting the balance between the landlord and tenant, most notably by discarding the archaic notions of independent covenants and caveat emptor. Id. at 186 . Since its approval in 1972, the URLTA has gained widespread acceptance with many states enacting legislation either modeled after it or influenced by it. Id. at 185 .

124. Powell, supra note 121. Three cases, in particular, are responsible for the downfall of traditional landlord tenant principles concerning residential tenancies. Whetzel v. Jess Fisher Management Co., allowed a tenant's tort suit to proceed based on the landlord's violation of a code provision; Edwards v. Habib permitted a tenant to defend an eviction on the grounds the landlord has retaliated against her for reporting code violations; finally, in Jarvis v. First National Realty Co., the court implied a warranty of habitability in residential leased premises. Glendon, supra note 114, at 521.

125. Glendon, supra note 114 , at 528-29.

126. Marden v. Radford, 84 S.W.2d 947, 954 (Mo. Ct. App. 1935).

127. $I d$. 
landlord and tenant relationship exists. ${ }^{128}$ Whether a tenancy is created depends on the intent of the parties. ${ }^{129}$ Intent may be determined from the express language of the agreement, or in the absence of clear intent, may be implied from the parties' conduct and attendant circumstances. ${ }^{130}$ The law has traditionally recognized four types of tenancies: (1) the tenancy for a term of years, ${ }^{131}$ (2) the periodic tenancy; ${ }^{132}$ (3) the tenancy at will; ${ }^{133}$ and (4) the tenancy at sufferance. ${ }^{134}$ A lease creates a possessory interest in property in favor of the tenant, the principal feature of which is the tenant's right to exclusive possession of the premises. ${ }^{135}$ It is this feature that distinguishes a tenant's interest from a mere license, which is a non-possessory right to use the property of another. ${ }^{136}$

As previously discussed, at common law the landlord's principal obligation was to convey possession of the land to the tenant in return for the tenant's agreement to pay rent. ${ }^{137}$ Implied in the lease were the covenants of quiet enjoyment and the tenant's covenant to pay rent, which were deemed independent of one another. ${ }^{138}$ Thus, the landlord had no duty to guarantee the habitability of the leased premises, had no duty to maintain or repair, and was furthermore immune

128. See Thompson, supra note $99, \S 39.06(a)(7)$.

129. Id. $\$ 39.06(\mathrm{a})(1)$.

130. Id. § 39.06(a)(7).

131. A lease is for a term of years if it establishes a fixed duration for the lease; that is, it must have a certain beginning date and must specify in advance the ending date of the tenancy. Thompson, supra note 99, §39.05(a). The duration of the term for years may be as short as a specified number of days or as long as the parties specify, absent a statute limiting the duration. Id.

132. In contrast to a term for years, a periodic tenancy has no definite ending date and continues from period to period until either party gives proper notice to terminate. $I d$. $\$ 39.05(\mathrm{~b})(2)$. A periodic tenancy may be created by the express intent of the parties or may be implied from the parties' course of dealing in the absence of clear intent. Id. §39.05(b)(3). Additionally, a periodic tenancy may arise in three other ways: 1) as the result of an invalid attempt to create a tenancy for years; 2) by the landlord choosing to obligate a holdover tenant under a new lease coupled with periodic payments of rent; and 3) when a tenant under a tenancy at will makes regular periodic payments of rent, which the landlord accepts. $I d$.

133. A tenancy at will is not measured by any specific period of time and continues as long as both parties mutually agree to its existence; any action inconsistent with its continuation terminates the tenancy. Id. $\S 39.05(\mathrm{~d})$. The parties may agree to create a tenancy at will, although most often this tenancy is created by operation of law and typically exists only for a short while, eventually being treated as a periodic tenancy. Id.

134. Although not a tenancy in a true sense, the tenancy at sufferance exists "because of the unauthorized retention of possession of a tenant whose landlord has not yet acted in response to the wrongful actions of the holdover tenant." Id. § 39.05(c). It should be noted that, practically speaking, only two types of tenancies are commonly used: the term for years and periodic tenancy. $I d$. This is true in many states, including those that have adopted the URLTA. Id. § 39.05 .

135. ThOMPson, supra note $99, \S 39.04$.

136. $I d$.

137. Love, supra note 97 , at 32.

138. Id. 
from liability in tort for injuries to persons or property owing to a defect in the premises. ${ }^{139}$ Moreover, a landlord could terminate a tenant's lease for any reason or for no reason at all, and could recover possession either by self-help or by an action in ejectment. ${ }^{140}$

Currently, the majority of jurisdictions impose a duty on the landlord to deliver and maintain the premises in a habitable condition, termed an "implied warranty of habitability." 141 A tenant's obligation not to commit waste has been, in many cases, supplanted by codes, statutes, and case law, which typically impose on tenants the duty not to harm the leased premises and "observe certain standards of cleanliness and appropriate use." 142 A landlord's breach of the implied warranty of habitability entitles the tenant to terminate the lease, in addition to all the usual contract remedies available for breach of warranty. ${ }^{143}$ Although courts have been more cautious in imposing tort liability on landlords, three approaches to determining liability have emerged. ${ }^{144}$ First, some courts adhere to the principal of immunity from liability, subject to a few exceptions. ${ }^{145}$ Second, courts in a few states have completely abrogated the doctrine of landlord immunity instead replacing it with the general standard of tort liability. ${ }^{146}$ Third, in rare instances, courts have imposed strict liability on the landlord for breach of an implied warranty or statutory duty to maintain the premises. ${ }^{147}$ Following a tenant's breach, the landlord now has recourse to summary process proceedings for the recovery of possession; the right to self-help may be reserved in some rare instances, although most courts have drastically limited this remedy. ${ }^{148}$ Finally, the landlord's right to possession upon termination of the lease has become qualified on the basis that a landlord may not evict a tenant or terminate the lease for certain statutorily prescribed reasons. ${ }^{149}$

139. Glendon, supra note 114, at 514-17.

140. Powell, supra note 121, § 17.01.

141. Kelley, supra note 102, at 1595.

142. Glendon, supra note 114, at 529; Unif. Residential Landlord-Tenant Act (URLTA) § 3.101 (UNIF. LAW COMMISSION) (listing duties of a tenant).

143. Glendon, supra note 114 , at 532. In many jurisdictions a tenant is authorized to remain in possession of the premises and withhold rent, although "this remedy is often carefully circumscribed with preconditions and safeguards." Id. at 533.

144. Id. at 535; Powell, supra note 121, § 16B.08.

145. Glendon, supra note 114 , at 536-36.

146. $I d$.

147. $I d$.

148. Powell, supra note $121, \S 17.01$.

149. Glendon, supra note 114 , at 540. For example, a landlord cannot terminate or refuse to rent on the basis of race, color, sex, religion, or national origin. Further restrictions have been placed on evictions in states and municipalities where the number of rental units has been dramatically decreased by their conversion into condominiums. Id. at 542. Additionally, a landlord must have "good cause" to evict in most rent-controlled jurisdictions and in public housing programs. Id. 


\section{B. The Law of Innkeepers}

An understanding of the common law origins of the law of innkeepers is likewise essential to understanding its evolution and modern day application. The following Sections outline the common law development of the law of innkeepers and discuss modern statutory developments before finally considering the defining characteristics of the innkeeper and guest relationship.

\section{Historical Context}

As with landlord and tenant law, the law of innkeepers developed in England during the Middle Ages. ${ }^{150}$ At this time, there was a good amount of traveling on foot and by horseback despite the terrible road conditions and ever-present danger of attack by outlaws and robbers. ${ }^{151}$ As a result, travelers were obliged to carry very light weight baggage and to secure protection from thieves and outlaws at night. ${ }^{152}$ Because travelers could not conveniently carry food with them on the road or risk sleeping out in the open, roadside inns were established throughout Medieval England in order to provide food and drink, nighttime accommodations, and even entertainment to weary travelers. ${ }^{153}$ The fundamental characteristic of inns at this time was their public nature; that is, the inn was viewed as a house "kept publicly, open, and notoriously, for the entertainment and accommodations of travelers and others, for a reward." ${ }^{54}$ It follows that the innkeeper was engaged in public employment and, as such, his primary duty was to serve every traveler who sought respite at his inn. ${ }^{155}$ This duty required innkeepers to provide adequate service at a reasonable price, and further, to serve members of the public equally and without discrimination. ${ }^{156}$

The innkeeper was one who, on his own account, not only professed to serve the public by keeping an inn, but also made it his regular business to do so. ${ }^{157}$ Because the innkeeper undertook to serve the needs of transient guests (that is, individuals staying at the inn for a brief period during the course of their travels), one who did not serve

150. John E. H. Sherry, The Law of InnKeepers 4 (3d ed. 1993).

151. Id.

152. See id. at 5 .

153. Id. There are several important differences between the inn and the alehouse or tavern at this time. The former was instituted for travelers; provided food; and was open at night for the protection of travelers. Id. at 6 . The latter, on the other hand, served the local population; furnished drink "for the mere pleasure of neighbors"; and turned its guest out upon closing time. Id.

154. Id. at 9 .

155. Id. at $9-10$.

156. John Henry Beale, Jr., The Law of InnKeepers and Hotels 36 (1906).

157. Sherry, supra note 150 at 10 . At common law, the right to keep an inn was unrestricted. BEALE, supra note 156, at 29. 
transient guests was not an innkeeper. ${ }^{158}$ The innkeeper was thus distinguished from private householders, who would occasionally, and even frequently, receive travelers in their homes for compensation, on the ground that these private householders did not make it their business to receive such travelers. ${ }^{159}$ The innkeeper did not need to declare his readiness to serve the public by any special means; instead, it was sufficient if the innkeeper made his intention to do so public "by word or by act." ${ }^{160}$ Stated differently, the innkeeper was one who, by any method, solicited the patronage of the public. ${ }^{161}$

The respective rights, duties, and responsibilities of an innkeeper and his guest have their origin in public policy, as one of the main purposes of the inn was to secure the protection of travelers and their property. ${ }^{162}$ In general, the innkeeper's duties to his guest were divided into three classes: the provision of shelter, protection, and food. ${ }^{163}$ Thus, the innkeeper was obligated to provide reasonably safe premises; furnish accommodations, ${ }^{164}$ exercise reasonable care in the protection of the guest ${ }^{165}$ protect the guest from injury by third parties; ${ }^{166}$ and supply as much food as the guest reasonably required. ${ }^{167}$ In addition, an innkeeper was responsible for the goods of his guest. ${ }^{168}$ This responsibility could not be limited by contract and it extended to goods that were bailed to the innkeeper (i.e., put into his possession for a particular purpose, generally for safekeeping), goods that remained in the guest's possession, ${ }^{169}$ and goods of the guest that were either lost or stolen from the inn. ${ }^{170}$

The innkeeper could eject a guest for proper cause, for example, due to intoxication or for otherwise "making a disturbance." 171 Additional grounds for ejection included a guest's contraction of a contagious disease or a guest's refusal to pay after falling into arrears and

158. SHERRY, supra note 150 , at 11.

159. Id. at 10; Lyon v. Smith, 1 Morris, 184, 186 (Iowa 1843).

160. BeAle, supra note 156, at 19; SHERRY, supra note 150, at 15.

161. SHERRY, supra note 150 , at 15.

162. Id. at $15-16$.

163. BeALE, supra note 156 , at 109.

164. Id. at $110-15$.

165. Id. at 118 .

166. Id. To be sure, the innkeeper was not the insurer of his guest's safety; nonetheless, the innkeeper had the duty to protect his guests, to the best of his ability, through reasonable means. $I d$. at 123 .

167. Id. at 117.

168. BEALE, supra note 156 , at 97,145 . This responsibility was not limited to goods of a particular kind; rather, it extended to money and all other personal property the guest brought into the inn. Id. at 136.

169. Id. at $98,102$.

170. Id. at 126,131 . This was true even though the loss or theft of the goods was without actual negligence on the part of the innkeeper. Id. at 135. The innkeeper was not liable, however, if goods were lost due to an act of God or of a public enemy or through the fault of the owner. Id. at 131-32.

171. BeAle, supra note 156, at 71. 
upon demand for payment by the innkeeper. ${ }^{172}$ Further, an innkeeper was justified in excluding a guest if that guest ceased to be a guest and had become a resident instead. ${ }^{173}$

Finally, because the law imposed upon the innkeeper a duty to receive all those who presented themselves as guests at his inn, the law gave the innkeeper not only the right to compensation from the guest, but also a lien on the guest's goods to the extent of his unpaid charges. ${ }^{174}$ Unlike other common law liens, the innkeeper did not need to have actual possession of the goods in order to enforce the lien. ${ }^{175}$ Thus, the innkeeper could prevent the goods from being removed from the inn, take the goods into his own possession, and hold the goods as security for payment. ${ }^{176}$

\section{Modern Developments}

In contrast to landlord and tenant law, which has undergone significant reform, the law of innkeepers has persisted without significant change from the common law, except with respect to innkeeper's liens and an innkeeper's liability for his guest's property. This Section highlights some ways in which the common law of innkeepers has changed over time before discussing the more significant statutory developments.

First, the term "innkeeper" has become obsolete except in legal terminology ${ }^{177}$ as "hotel keeper,"178 "tavern keeper,"179 and similar terms have been considered synonymous with "innkeeper." Likewise, the common law definition of an innkeeper-one who holds himself open to the public to receive guests for compensation $-{ }^{180}$ has been broadened by statute to include the proprietor "of any hotel, inn ... or motel where beds or lodging are for hire." 181 It follows from this that modern-day hotels, motels, and like establishments have succeeded to the role of the medieval roadside inn. ${ }^{182}$ Thus, an establishment that provides accommodations to travelers for a fee may be

172. Id. at $71-73$.

173. Id. at 73. In this last respect, the innkeeper had to justify such exclusion by making an affirmative showing the guest was no longer a traveler, but had become a resident. $I d$. In making this determination the length of residence was a relevant factor, although not dispositive. Id.

174. Id. at 175-76. The lien attached upon receipt of the guest at the inn, even though the time for payment had not yet arrived. $I d$. at 188 .

175. Id. at 176 .

176. Id.

177. Langford v. Vandaveer, 254 S.W.2d 498, 500 (Ky. 1953).

178. McClaugherty v. Cline, 163 S.W. 801, 801 (Tenn. 1913).

179. Bonner v. Welborn, 7 Ga. 296, 306 (1849).

180. See supra text accompanying notes 160-61.

181. Williams v. Riley, 289 S.E.2d 102, 104 (N.C. Ct. App. 1982); see also UtAH Code Ann. § 29-2-102 (West 2015); see also Okla. Stat. Ann. tit. $15 \S 505$ (West 2015); see also Minn. Stat. Ann. $\$ 327.70$ (West 2015); see also Kan. Stat. Ann. $\S \S 36-501,36-601$ (West 2015).

182. Thompson, supra note $99, \S 52.02$. 
properly characterized as an inn regardless of its physical structure or name. ${ }^{183}$

At common law, it was essential that a person seek both food and accommodations in order to be a guest ${ }^{184}$ modernly, it is sufficient that a person only seek accommodations. ${ }^{185}$ The innkeeper's broad liability for the loss of or damage to the property of his guests has, in every jurisdiction, been limited by statute to some extent. ${ }^{186}$ The most common of these provisions set monetary limits on the loss of items that are retained by the guest, deposited with the establishment for safekeeping, or in some instances both. ${ }^{187}$ Notice of a secure place for the safekeeping of valuables is an important component in many rules limiting an innkeeper's liability, and in some jurisdictions, a guest who receives proper notice and thereafter ignores it is barred from recovery. ${ }^{188}$ Finally, almost all jurisdictions provide for a statutory lien under which an innkeeper may retain possession of luggage or other personal property of his or her guest as security for payment. ${ }^{189}$

\section{The Innkeeper and Guest Relationship}

In order to establish the innkeeper and guest relationship, a guest must first communicate his intention to be received as such and the innkeeper must have the opportunity to either receive or reject the guest. ${ }^{190}$ If the guest thus "presents himself" and is accepted, the relationship "is instantly established between them" and the rights and duties of both parties are at once fixed by law rather than by contract. ${ }^{191}$ This result follows from the fact that, once a guest is admitted to an inn, the innkeeper's obligation to care for him is imposed by law and not by the will of the parties. ${ }^{192}$ The relationship is terminated upon the guest paying his bill and leaving the inn without any intention of returning. ${ }^{193}$ Finally, the guest receives a mere license granting him the use and occupancy of the premises. ${ }^{194}$

183. Langford v. Vandaveer, 254 S.W.2d 498, 500 (Ky. 1953).

184. See supra text accompanying notes 163-64, 167.

185. See Ala. Code $§ 34-15-1$ (2015) (defining a hotel as any establishment where sleeping accommodations are held out to be available to transients).

186. Thompson, supra note $99, \S 52.05(\mathrm{a})$.

187. $I d$.

188. Id. § 52.05(b).

189. Id. §52.10(a).

190. BEALE, supra note 156 , at 79 .

191. Id. at $75,78-79$.

192. Id. at 75, 78-79. Although a contract is not necessary, there must still exist a mutual intent to receive and be received in order for the relationship to exist. Id.

193. Id. at 162 .

194. Kearny v. Mun. Sanitary Landfill Auth., 363 A.2d 390, 394 (N.J. Super. Ct. Law Div. 1976). 


\section{Analysis of the Airbnb "Host" and "Guest" RELATIONSHIP}

Classifying the Airbnb "host" and "guest" relationship in terms of landlord and tenant law or the law of innkeepers is determinative of the legal obligations and rights of both parties. However, it is not so easy to classify these relationships in terms of these discrete areas of law, which is largely due to the way these relationships are created and the disparate expectations of the parties who create them. As we saw in the introduction, an excellent example of this disparity is the case of Cory Tschogl and her Airbnb guest-turned-squatter. ${ }^{195}$

The following Section distinguishes between the principle features of landlord and tenant law and the law of innkeepers before considering Tschogl's experience in the context of each area of law. This is done in order to highlight the difficulties in classifying these relationships and resulting disparity in the rights and obligations of both parties. Next, this Section argues that the Airbnb host and guest relationship is best understood, and should be regulated, in the context of the law of innkeepers. Finally, this Section briefly considers policy arguments in support of regulation.

\section{A. Landlord and Tenant Law and the Law of Innkeepers Distinguished}

Under landlord and tenant law, the relationship between the parties arises by agreement, express or implied, pursuant to which a tenancy or lease is created in favor of the tenant. ${ }^{196}$ A lease is a possessory interest in property, the principal feature of which is the tenant's exclusive possession of the premises. ${ }^{197}$ The primary obligation of the tenant is to pay rent. ${ }^{198}$ The landlord, on the other hand, impliedly covenants that the tenant's use and enjoyment of the premises will not be disturbed and that the premises are fit for habitation. ${ }^{199}$ The landlord must maintain the premises in a habitable condition and may be held liable for injury to persons or property owing to a defect in the premises. $^{200}$ In general, a landlord may not resort to self-help repossession of the premises and must instead pursue summary process proceedings. ${ }^{201}$ Finally, a landlord may not evict a tenant for certain prescribed reasons. ${ }^{202}$

Under the law of innkeepers, the relationship between the parties is implied by law or in some cases arises under contract when the inn-

195. See supra Part I.

196. See discussion supra Part III.A.3.

197. See discussion supra Part III.A.3.

198. See discussion supra Part III.A.3.

199. See discussion supra Part III.A.3.

200. See discussion supra Part III.A.3.

201. See discussion supra Part III.A.3.

202. See discussion supra Part III.A.3. 
keeper receives a guest seeking accommodations. ${ }^{203}$ In contrast to a tenant, who receives a possessory interest property, the guest receives only a license, which is merely permission to use land for a specified purpose with no interest in or exclusive possession of the land. ${ }^{204} \mathrm{Sim}$ ilar to the landlord's implied covenant of habitability, the innkeeper must provide premises that are reasonably safe. Unlike the landlord, however, the innkeeper must not only provide reasonably safe accommodations but has an affirmative duty to exercise reasonable care in the protection of the guest and to protect the guest against third parties. An innkeeper may resort to self-help to eject a guest who is "unruly and disorderly," 205 among other reasons, whereas a landlord must follow the relevant statutory procedures for eviction, and even then the landlord is limited in the grounds he can assert to evict a tenant. Generally speaking, a landlord is not responsible for safeguarding his tenant's property. This difference is because the exclusive possession of the premises is given over to the tenant, who, being in the better position to protect his property, has the responsibility of doing so. In contrast, an innkeeper may be held liable for the loss of, theft, or damage to the guest's property. Finally, the innkeeper receives a lien over the guest's property as security for payment, whereas the landlord generally does not.

\section{B. Classifying Airbnb "Hosts" and "Guests"}

As we saw earlier, Cory Tschogl had difficulty "making ends meet" with high rent rates in San Francisco, so she invested in a vacation rental condo in Palm Springs which, she then rented out to travelers through Airbnb. ${ }^{206}$ This arrangement worked well for about a yearafter all, Tschogl was able to earn the extra income she needed through the minimal effort of listing her condo and booking reservations using Airbnb's online platform. ${ }^{207}$ This changed, however, when Tschogl rented her condo to the proverbial "guest from hell" who, despite being twice asked to leave, complained about the accommodations, overstayed his reservation, failed to pay the full reservation cost, and threatened legal action against Tschogl. ${ }^{208}$ Ultimately, Tschogl resorted to eviction proceedings to oust the Airbnb guest-turned-squat-

203. See discussion supra Part III.B.3.

204. Poroznoff v. Alberti, 391 A.2d 984, 987 (Passaic County Ct. 1978), aff'd, 401 A.2d 1124 (N.J. Super. Ct. App. Div. 1979) (noting a guest is a mere licensee with only a right of use of the room he occupies).

205. Id. at 988.

206. See supra Part I.

207. See supra Part I.

208. See supra Part I. 
ter, and "after an arduous two months," 209 finally reclaimed her condo.

It is unclear whether Tschogl, a rehabilitation therapist, understood that renting her condo to travelers created a legal relationship between the parties, pursuant to which certain rights and obligations are accorded. After all, no laws were in place regulating Airbnb at the time and the company did little (if anything) to educate its users about the potential legal consequences of using its platform to facilitate these transactions. Even assuming Tschogl realized that the agreement between her and her guest created a legal relationship, it is evident from Tschogl's interactions with her guest that she did not fully appreciate the parties' respective rights and obligations arising under the agreement. This is not surprising, however, because of the inherent difficulty in classifying the relationship between the parties as either landlord and tenant or innkeeper and guest. As the following Section illustrates, the relationship between Tschogl and her guest could reasonably be classified as either.

Under landlord and tenant law, for example, the four requirements to create a landlord and tenant relationship were likely met in Tschogl's case. ${ }^{210}$ First, Tschogl was the owner of the condo and thus was entitled to its possession once her guest's reservation ended. Second, Tschogl agreed to rent her condo to her guest for a little over a month, which rental period having a definite beginning and ending could reasonably be viewed as a tenancy for a term of years. ${ }^{211}$ Third, Tschogl transferred the exclusive possession of her condo to her guest for the duration of his reservation in exchange for a fee. Lastly, this arrangement was made possible as the result of the parties' express agreement.

If a landlord and tenant relationship was created between Tschogl and her guest, certain rights and obligations were at once fixed between the parties whether they realized it or not. Thus, the guest's complaints about the quality of the tap water (assuming they were credible) raise concerns about Tschogl's potential liability for breach of implied warranty, as does Tschogl's warning she would shut off the utilities if the guest did not leave. Furthermore, Tschogl would have been required to pursue eviction proceedings against her guest even in the absence of the California law which, in this case, treated her guest as a tenant on a month-to-month lease.

Under the law of innkeepers, the innkeeper and guest relationship was likely established, too, once the guest booked his reservation (thereby notifying Tschogl of his intent to be received as a guest at her

209. Skip Descant, Airbnb Squatter Checks Out of Palm Springs Apartment, USA TodAy (Aug. 20, 2014, 7:24 PM), http://www.usatoday.com/story/money/business/ tourism/2014/08/20/airbnb-palm-springs-squatter/14362779/.

210. See discussion supra Part III.A.3.

211. See supra note 131. 
condo in exchange for compensation), and Tschogl's subsequent acceptance, in which case the rights and duties of the parties were instantly fixed by law. In contrast to landlord and tenant law, the guest here would have received a mere license to use Tschogl's condo, which license is generally revocable at will. Thus, it would have been well within Tschogl's rights to terminate her guest's reservation solely because she had a "bad gut feeling" about him. ${ }^{212}$ After allowing him to stay, however, Tschogl would have had the heightened duty of an innkeeper to provide safe accommodations as well as provide for the safety of her guest and his belongings. After Tschogl's guest failed to pay for the full reservation, Tschogl would likely have had a statutory lien on her guest's property to the extent of the charges due, and moreover, Tschogl could have summarily ejected her guest without resorting to eviction proceedings. Additionally, Tschogl could have ejected her guest on the grounds he intended to remain in the condo as a resident rather than as a guest.

Tschogl's experience is illustrative of the difficulty in classifying the types of relationships that are created when, using Airbnb's online platform, individuals rent space in their homes to travelers seeking short-term accommodations. This is merely one example, however. As previously noted, Airbnb currently lists accommodations of varying degrees in more than 190 countries and has hosted more than 11 million guests to date. ${ }^{213}$ Every transaction that Airbnb facilitates is unique with respect to the location, accommodations offered, and length of stay, among other features. However, the relationships created between the parties are not; rather, they may reasonably be classified as either a landlord and tenant relationship or innkeeper and guest relationship. Because of the difficulty in classifying these relationships correctly, and consequent uncertainty in the corresponding rights and duties of the parties, states and municipalities should enact legislation clearly defining these relationships at their outset. ${ }^{214}$

\section{Approach to Regulation}

The relationship between Airbnb hosts and guests is best understood in terms of the law of innkeepers and should be regulated accordingly. This is because the relationship between an Airbnb host and his guest more closely resembles that of an innkeeper and his guest insofar as the host agrees to provide short-term accommodations to travelers for a fee. ${ }^{215}$ Apart from this outward appearance in

212. Bort, supra note 1.

213. See supra Part II.B.2.

214. Some jurisdictions have, in fact, enacted laws regulating Airbnb and similar companies; these approaches to regulation vary in degree by municipality. See Gottlieb, supra note 36.

215. The fact that, at common law, an innkeeper was one who professed to serve the public should not prevent modern-day Airbnb hosts from being considered as 
similarity, the expectations of the parties are likely best represented by the innkeeper and guest relationship. To be sure, the Airbnb host has succeeded to the role of the hotel proprietor and hotel rooms have been replaced with the private homes of individuals. ${ }^{216}$ Despite this change in setting, however, the parties' expectations remain largely unchanged-the Airbnb host is interested in earning a profit in exchange for permitting the limited use of his premises, whereas the Airbnb guest is concerned with securing safe, pleasant accommodations for the duration of his stay. Because of this similarity in expectations, it is likely that Airbnb hosts and guests intend to enter into an innkeeper and guest relationship, rather than that of a landlord and tenant, when accommodations are made for short-term accommodations. Thus, states and municipalities should expand the modern day application of the law of innkeepers to include Airbnb hosts and guests in certain narrowly tailored circumstances. This approach recognizes the expectations of the parties and provides a framework for understanding their respective rights and obligations.

\section{Policy Arguments for Regulating Airbnb}

As noted above, the difficulty in classifying Airbnb hosts and guests raises concerns regarding the parties' respective rights and obligations under the law. The following Section outlines public policy arguments in support of regulating these relationships when, as is inevitable, disputes arise between the parties. Specifically, regulation is appropriate in order to protect individuals and promote efficiency in adjudicating claims that may arise.

\section{Protecting Airbnb Hosts and Guests}

As an initial matter, it is appropriate for states and municipalities to enact laws regulating the legal relationship between Airbnb hosts and guests for two reasons. First, it is well within a state's police power to regulate hotels and similar establishments for the public health and safety of its guests, which concerns are particularly relevant to the Airbnb host and guest relationship. ${ }^{217}$ After all, at the heart of this relationship is essentially an agreement between strangers whereby one invites the other to stay in his home for a fee. In contrast to hotels

such. Indeed, although the typical Airbnb host may not hang a welcome sign over his door, by listing his home as available for rent through Airbnb's online platform, it cannot be reasonably said that, in doing so, he does not "profess to serve the public." See supra text accompanying notes 160-61.

216. That these arrangements are similar to hotels is further evidenced by the fact that several jurisdictions impose a transient occupancy tax on Airbnb guests, which tax has before only applied in the context of hotels. See Ann Carrns, Lodging Taxes and Airbnb Hosts: Who Pays and How, N.Y. Times (June 26, 2015), http://www.nytimes.com/2015/06/17/your-money/lodging-taxes-and-airbnb-hosts-who-pays-and-how .html?_r=0.

217. Texarkana v. Brachfield, 207 Ark. 774, 780, 183 S.W.2d 304, 307 (1944). 
(which are in the business of providing travel accommodations and are subject to considerable regulation), guests who book reservations in the homes of private individuals through Airbnb do so at their own risk. Further, an Airbnb host's principal interest, similar to a hotel, is to earn a profit. However, unlike a hotel, a host is less likely to realize the extent of his legal obligations, if he realizes them at all. Although Airbnb users may self-regulate these transactions to some degree (for example, by posting user reviews and using social media sites to verify one's identify) these transactions largely operate without the oversight of Airbnb and, in most cases, local governments. Thus, these arrangements are, at least potentially, open invitations for a number of safetyrelated concerns.

Second, states and municipalities should enact laws regulating these relationships from a consumer protection standpoint. Consumer transactions are typically defined as those for "personal" or "family" purposes. ${ }^{218}$ It is likely that, in a majority of cases, a guest who books travel accommodations through Airbnb does so either for personal or family reasons; therefore, it is appropriate to characterize these as consumer transactions. ${ }^{219}$ Both state and federal governments have enacted laws for the protection of consumers on the basis that, in general, consumers lack the bargaining power and expertise of the other party to the transaction. ${ }^{220}$ Because Airbnb is largely unregulated, it is perhaps impossible to gauge the varying degrees of bargaining power and expertise that exists between Airbnb hosts and guests. However, the potential exists for there to be a great disparity in terms of the respective bargaining power and expertise of Airbnb hosts and guests. This disparity is evidenced by the fact that, in some areas, Airbnb hosts manage multiple listings, which they rent year-round to guests. ${ }^{221}$ Likewise, a guest experienced with booking accommodations through Airbnb may be in a position to take advantage of an inexperienced host. This eventuality is apparent in Tschogl's case, where her Airbnb guest seemed to know exactly what he could "get away with." This is not to suggest that laws enacted to protect consumers should benefit those who, like Tschogl's guest, take advantage of the system. Rather, the goal of such legislation should be to provide a

218. James H. Backman, The Tenant as Consumer? A Comparison of Development in Consumer Law and in Landlord/Tenant Law, 33 OKLA. L. Rev. 1, 3 (1980).

219. In fact, as of July 2014 only about $10 \%$ of Airbnb's customers were business travelers. Mike Isaac, Airbnb Expands Into Business Travel, Bits, N.Y. TimEs, (July 28, 2014, 4:39 PM), http://bits.blogs.nytimes.com/2014/07/28/airbnb-expands-into-business-travel/?_r=0. This will likely change, however, in light of the company's business travel initiative. $I d$.

220. See generally Backman, supra note 218 (discussing the applicability of consumer laws in the area of landlord and tenant law). Typically these transactions concern residential landlords, producers, suppliers, or servicemen. Id. at 3.

221. See, e.g., Eric T. Schneiderman, N.Y. State Office of the Attorney Gen., Airbnb in the City 10 (2014), http://www.ag.ny.gov/pdfs/Airbnb\%20report .pdf. 
level playing field for hosts and guests alike, while also guarding against potential abuse by either party.

\section{Judicial and Administrative Efficiency}

In the early 20th century population expansion and improved construction methods dramatically changed the character and increased the importance of rental housing, and in the ensuing years, courts struggled to determine the legal obligations and rights of owners and occupants of rented premises. ${ }^{222}$ Courts ultimately classified a particular occupant as a tenant, lodger, or guest in order to make this determination and, in doing so, focused primarily on the living conditions of the occupant of the rented premises. ${ }^{223}$ This sort of ad hoc classification was not only inefficient, but it left too much room for judicial discretion. From this followed several results: decisions often turned on the presence or absence of a particular factor; ${ }^{224}$ the exclusiveness of the occupancy became the principal focus to the exclusion of other factors: ${ }^{225}$ and favoritism toward contractual clauses led to a disregard of the parties' express intent. ${ }^{226}$

It is likely that, in the advent of Airbnb and the Sharing Economy, courts will again be required to determine the rights and duties of both renters and occupants. In order to promote administrative efficiency, and avoid ad hoc classification of these relationships based on the factors in a particular case, states and municipalities should enact laws that define these relationships at their outset. Such an approach to regulation leaves little room for judicial discretion, which, in turn, leads to the consistent application and better understanding of applicable laws. Moreover, legislators are better suited to enact laws addressing these relationships than courts because they can do so quickly and comprehensively.

\section{Conclusion}

Airbnb and the Sharing Economy are revolutionizing the way host and guest relationships are created by providing an online platform through which individuals can easily and efficiently connect to share space in their homes on a short-term basis for profit. As previously noted, there are many benefits to these types of arrangements for Airbnb hosts and guests alike. However, difficulty exists in determining the respective rights and obligations of hosts and guests because this relationship has been taken out of the traditional hotel setting, where the law of innkeepers reigns, and instead, has been placed in

222. See Comment, Tenant, Lodger, and Guest: Questionable categories for Modern Rental Occupants, 64 Yale L.J. 391, 391 (1955).

223. Id. at 391-92.

224. Id. at 396.

225. Id. at 402 .

226. Id. at 403. 
the homes of private individuals where landlord and tenant law predominately prevails. Because of this difficulty, states and municipalities should enact laws defining the Airbnb host and guest relationship in terms of the law of innkeepers because the parties' expectations are more closely in line with those of an innkeeper and his guest. Such an approach to regulation will have two results. First, this will reduce or altogether eliminate the potential for disparity between the bargaining power and expertise of hosts, which protects both parties and guards against potential abuses. Second, hosts and guests will have a clear understanding of their respective rights and obligations at the outset of the relationship, which promotes efficiency in adjudicating any disputes that may arise and avoids the problem of courts making ad hoc classifications based on varying circumstances in a particular case. 
